\title{
Checklists for Powder Inhaler Technique: A Review and Recommendations
}

\author{
Iman A Basheti PhD, Sinthia Z Bosnic-Anticevich PhD, \\ Carol L Armour PhD, and Helen K Reddel PhD \\ Introduction \\ Review of the Literature \\ Search Strategy \\ Published Inhaler Technique Checklists and Reporting Systems \\ Number and Categorization of Steps \\ Scoring and Reporting Systems for Inhaler Technique Checklists \\ Source of Information for Checklists \\ Summary \\ Evidence for Inclusion of Individual Technique Steps in Device Checklists \\ Evidence for Additional Steps \\ Essential Steps for the Turbuhaler and Diskus \\ Reporting Turbuhaler/Diskus Technique Data \\ Clinical Impact of Using Inhaler Technique Checklists \\ Conclusions
}

\begin{abstract}
Turbuhaler and Diskus are commonly used powder inhaler devices for patients with respiratory disease. Their effectiveness is limited in part by a patient's ability to use them correctly. This has led to numerous studies being conducted over the last decade to assess the correct use of these devices by patients and health care professionals. These studies have generally used device-specific checklists to assess technique, this being the most feasible and accessible method for assessment. However, divergence between the checklists and scoring systems for the same device in different studies makes direct comparison of results difficult and at times inappropriate. Little evidence is available to assess the relative importance of different criteria; however, brief patient training based on specific inhaler technique checklists leads to significant improvement in asthma outcomes. This paper reviews common checklists and scoring systems used for Turbuhaler and Diskus, discusses the problem of heterogeneity between different checklists, and finally recommends suitable checklists and scoring systems for these devices based on the literature and previous findings. Only when similar checklists are used across different research studies will accurate comparisons and meta-analysis be possible. Key words: inhalers; checklists; technique; pharmacists; scoring systems. [Respir Care 2014;59(7):1140-1154. @ 2014 Daedalus Enterprises]
\end{abstract}

Dr Basheti is affiliated with the Faculty of Pharmacy, Applied Science University, Amman, Jordan. Drs Bosnic-Anticevich, Armour, and Reddel are affiliated with the Woolcock Institute of Medical Research, University of Sydney, New South Wales, Australia.

The authors have disclosed no conflicts of interest.
Correspondence: Iman A Basheti PhD, Faculty of Pharmacy, Applied Science University, PO Box 166, Amman 11931, Jordan. E-mail: dr_iman@asu.edu.jo.

DOI: $10.4187 /$ respcare. 02342 


\section{Checklists for Powder Inhaler Technique}

\section{Introduction}

Powder inhaler devices have been developed over the last 2 decades for treatment of asthma and COPD. These small portable devices contain micronised powdered medication, often with a carrier, with the particles dispersed during inhalation. These devices were developed for use in adults and older children and have been shown to deliver drugs safely and effectively. ${ }^{1,2}$ Several types of powder inhalers are available, some as single-dose, capsule-based inhalers, such as the Aerolizer (Novartis, Basel, Switzerland), or HandiHaler (Boehringer Ingelheim, Ingelheim, Germany). More commonly, powder inhalers are multidose inhalers, either reservoir-type inhalers, such as the Turbuhaler (AstraZeneca, London, United Kingdom) (similar to the Flexhaler), Clickhaler (Vectura, Wiltshire, United Kingdom), Easyhaler (Orion, Espoo, Finland), and Novolizer (Meda, Solna, Sweden), or based on prefilled blisters, such as the Diskus Accuhaler (GlaxoSmithKline, Brentford, England), or blister disks, such as the Diskhaler (GlaxoSmithKline, Brentford, England).

The acceptance of powder inhalers has been driven in large part by the enormous success in recent years of combination treatment with a corticosteroid and a long-acting $\beta_{2}$ agonist. ${ }^{3}$ The combination of budesonide and formoterol fumarate dihydrate (Symbicort) in the Turbuhaler and fluticasone propionate and salmeterol xinafoate (Seretide) in the Diskus reflects current treatment guidelines for moderate to severe asthma and COPD. These devices have been found to be the most efficient and commonly used of the powder inhaler devices. ${ }^{4,5}$

Many factors play a role in the overall performance of the Turbuhaler ${ }^{6}$ (Fig. 1) and Diskus ${ }^{7}$ (Fig. 2), from their pharmaceutical formulations to their mechanical and aerodynamic properties and to the way they are used by people with airway disease. Correct device use is critical to the delivery of medication to the airways. Many studies have been conducted to assess and improve the way people use the Turbuhaler and Diskus. Some studies have used specific devices for assessing individual components of inhaler technique. For example, devices such as the Turbutest measure the patient's inspiratory flow through a placebo Turbuhaler. ${ }^{8,9}$ Portable devices for assessing some components of inhaler technique were recently reviewed. ${ }^{10}$ One example is the Inhalation Manager, which measures inspiratory flow through inhalation devices (including a stylized powder inhaler) using a pneumotachometer; this system also predicts drug delivery mass and particle deposition based on in vitro data. ${ }^{11}$ This instrument is proposed as a tool for assessing and training patients on correct inhaler technique and for identifying the most suitable inhaler for an individual patient, ${ }^{11}$ but it is not feasible on a wide scale and requires technical support. The Turbuhaler whistle

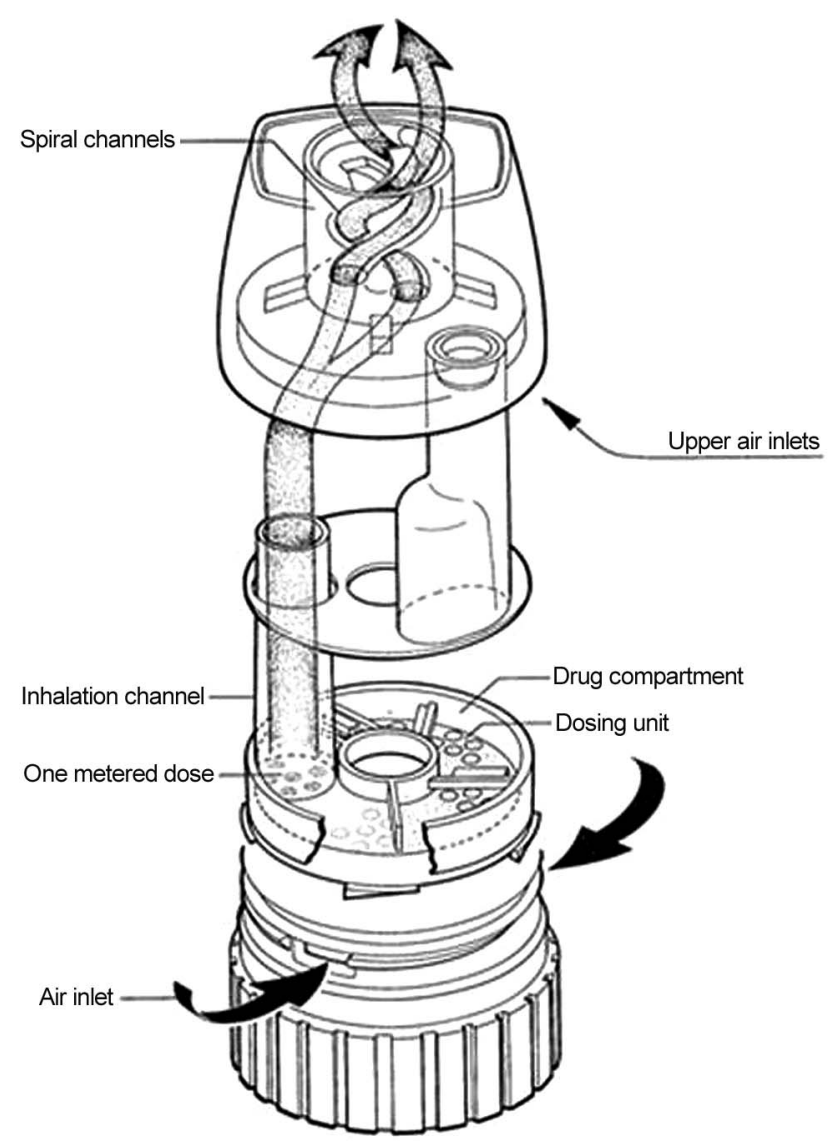

Fig. 1. Turbuhaler. Courtesy AstraZeneca.

(AstraZeneca Pharmaceuticals) is a simple device that whistles if the patient inhales $>35 \mathrm{~L} / \mathrm{s} .{ }^{12}$

However, by far the most common, feasible, and accessible method of assessing inhaler technique is through the use of device-specific inhaler technique checklists. The validity of inhaler technique checklists was initially established by Appel, ${ }^{13}$ who showed that trained personnel were able to achieve a $98 \%$ success rate in predicting the bronchodilator response for patients with asthma using their reliever devices by observing their inhaler technique. More recently, inhaler technique checklists have been shown to be feasible tools for assessment of technique. The clinical utility of inhaler checklists has been confirmed by studies with powder inhalers ${ }^{14}$ and pressurized metered-dose inhalers, ${ }^{15}$ which have shown that, when brief patient training was based on a standardized inhaler technique checklist, there were significant improvements in asthma outcomes. Hence, it can be concluded that assessment and correction of asthma patients' inhaler technique against a checklist are valid measurements of the effectiveness of the inhalation devices in terms of delivering improved clinical outcomes. 


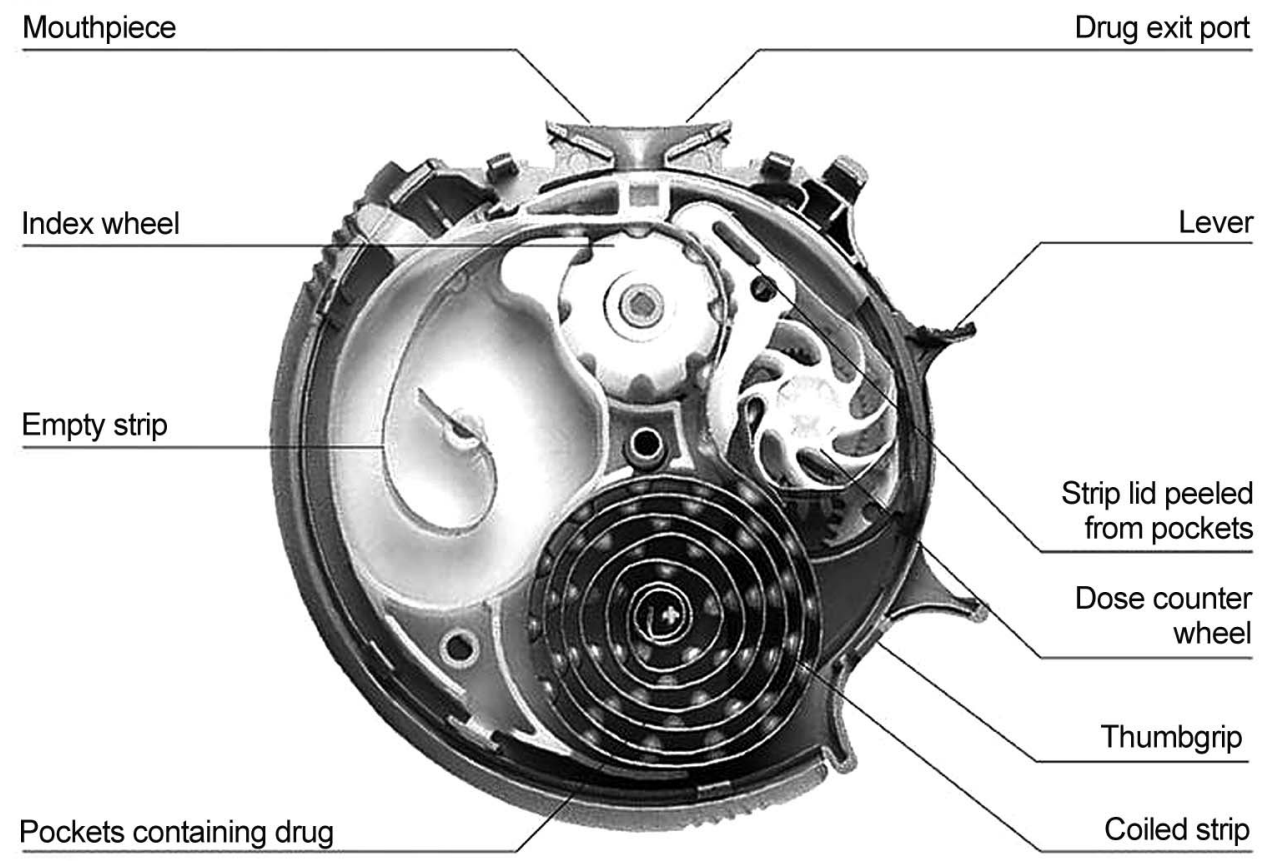

Fig. 2. Diskus. Courtesy GlaxoSmithKline.

A systematic review of the effectiveness of different inhaler devices in asthma and COPD noted problems in comparisons between studies because of variation in the relevant inhaler technique checklists. ${ }^{16}$ The objective of the present review was therefore to describe and compare the inhaler technique checklists and scoring systems reported for Turbuhaler and Diskus and to recommend uniform checklists and scoring systems for use in future studies and in clinical practice.

\section{Review of the Literature}

\section{Search Strategy}

The search strategy included PubMed, Embase, and International Pharmacy Abstracts up to 2012. Key words used for the search included "inhaler technique," "checklists," "Turbuhaler," "Turbohaler," “Accuhaler," "Diskus," and "incorrect use." The titles and abstracts of all articles produced by this search were assessed for inclusion before retrieval of full articles. These articles were then subsequently reassessed for inclusion, and only those presenting checklists for the Turbuhaler and/or Diskus and meeting the inclusion criteria were included in the review. No blinding of authors' names or institutions was done, and no scoring system for study quality was used. The inclusion criteria were studies of Turbuhaler or Diskus usage involving subjects with asthma or COPD and/or health care professionals. Only publications in the English language were included. Letters to editors, commentaries, cost analyses, and surveys were excluded. Instructions packaged with the inhaler devices themselves were also included.

\section{Published Inhaler Technique Checklists and Reporting Systems}

Twenty-six research articles were included in the analysis of inhaler technique checklists for the Turbuhaler and Diskus. Table 1 lists these checklists, together with the list of steps in the manufacturers' instructions.

\section{Number and Categorization of Steps}

The 24 different checklists for the Turbuhaler and 16 for the Diskus. It shows substantial variation between checklists in the number of steps listed, ranging from 3 to 14 steps for the Turbuhaler and from 3 to 13 steps for the Diskus. Most checklists included removing the Turbuhaler cap (19/24) or opening the Diskus cover (14/16), and all checklists included steps for loading a dose and inhaling the dose. However, first exhaling away from the mouthpiece was listed in fewer than half of checklists for both devices. The speed of inhalation, most often described as needing to be strong and forceful, was not mentioned in 4 of 24 Turbuhaler checklists and in 3 of 16 Diskus checklists. Almost all checklists included breath-holding after inhalation (21 of 24 for the Turbuhaler and 13 of 16 for the 


\section{Checklists for Powder Inhaler Technique}

Table 1. Checklists Used in the Assessment of Inhaler Technique in Clinical Studies for the Turbuhaler and Diskus

\begin{tabular}{|c|c|}
\hline Authors/Manufacturer & Turbuhaler Instructions \\
\hline $\begin{array}{c}\text { Manufacturers' } \\
\text { instructions }\end{array}$ & $\begin{array}{l}\text { There are additional instructions for first } \\
\text { use of Symbicort. } \\
\text { (1) Unscrew and lift off the cover. } \\
\text { (2) Hold your Turbuhaler upright with } \\
\text { the red grip at the bottom. } \\
\text { (3) Turn the red grip as far as it will go } \\
\text { in one direction and then turn it as far } \\
\text { as it will go in the other direction. } \\
\text { You should hear a click sound. } \\
\text { (4) Hold your Turbuhaler away from } \\
\text { your mouth. Breathe out gently (as } \\
\text { far as is comfortable). } \\
\text { (5) Place the mouthpiece gently between } \\
\text { your teeth. Close your lips. } \\
\text { (6) Breathe in as deeply and as hard as } \\
\text { you can through your mouth. } \\
\text { (7) Remove your Turbuhaler from your } \\
\text { mouth. } \\
\text { (8) Breathe out gently. } \\
\text { (9) If you are to take a second } \\
\text { inhalation, repeat steps } 2-6 \text {. } \\
\text { (10) Replace the cover tightly after use. } \\
\text { (11) Rinse your mouth with water after } \\
\text { your daily morning and/or evening } \\
\text { doses and spit it out. }\end{array}$ \\
\hline
\end{tabular}

Al-Doghim ${ }^{17}$

Basheti et al ${ }^{14}$

Basheti et al ${ }^{19}$
(1) Remove Cap

(2) Hold the inhaler upright, turn the grip to the right as far as it will go. and turn the grip back again to the left until it clicks.

(3) Exhale slowly.

(4) Place the mouthpiece between your teeth and lips.

(5) Inhale forcefully and deeply.

(6) Remove the inhaler from your mouth before breathing out.

(1) Remove the cap from the inhaler.

(2) Keep the inhaler upright.

(3) Rotate the grip counterclockwise and then back until a click is heard.

(4) Exhale to RV.

(5) Exhale away from the mouthpiece.

(6) Place the mouthpiece between teeth and lips.

(7) Inhale forcefully and deeply.

(8) Hold breath for $5 \mathrm{~s}$.

(9) Exhale away from the mouthpiece.

(1) Remove the cap from the inhaler.

(2) Keep inhaler upright on a flat surface.

(3) Rotate the grip counterclockwise and then back until a click is heard.

(4) Exhale to RV.

(5) Exhale away from the mouthpiece.

(6) Place the mouthpiece between teeth and lips.

(7) Inhale forcefully and deeply.

(8) Hold breath for $5 \mathrm{~s}$.

(9) Exhale away from the mouthpiece.
Stated Sources

(1) Hold the Diskus in one hand and put the thumb of your other hand on the thumb grip.

(2) Push your thumb away from you as far as it will go until the mouthpiece appears and snaps into position.

(3) Hold the Diskus in a level horizontal position with the mouthpiece towards you.

(4) Slide the lever away from you as far as it will go until it clicks.

(5) Before inhaling your dose, breathe out as far as is comfortable, holding the Diskus level and away from your mouth.

(6) Put the mouthpiece to your lips. Breathe in quickly and deeply through the Diskus, not through your nose.

(7) Remove the Diskus from your mouth. Hold your breath for $\sim 10 \mathrm{~s}$ or for as long as is comfortable.

(8) Breathe out slowly.

(9) Close the Diskus when you are finished taking a dose so that the Diskus will be ready for you to take your next dose.

(10) Put your thumb on the thumb grip and slide the thumb grip back towards you as far as it will go. The Diskus will click shut. The lever will automatically return to its original position.

Checklist based on previous studies

(1) Open the inhaler.

(2) Push the lever back completely.

(3) Exhale to RV.

(4) Exhale away from mouthpiece.

(5) Place the mouthpiece between teeth and lips.

(6) Inhale forcefully and deeply.

(7) Hold breath for $5 \mathrm{~s}$.

(8) Exhale away from the mouthpiece.

(9) Close the inhaler.
Manufacturers' instructions for the Symbicort Turbuhaler* and Diskus $\dagger$
Checklist based on previous study by van der Palen et $\mathrm{al}^{18}$
Checklist based on previous study by van der Palen et a ${ }^{18}$ 


\section{Checklists for Powder Inhaler Technique}

Table 1. Continued

\begin{tabular}{ll}
\hline \hline Authors/Manufacturer & Turbuhaler Instructions \\
\hline Cain et al ${ }^{20}$ & (1) Remove the cover. \\
(2) Turn the bottom clockwise until it clicks \\
while keeping the inhaler upright. \\
(3) Turn the bottom counterclockwise to the \\
maximum while keeping the inhaler upright. \\
(4) Turn head away from the inhaler and exhale \\
to FRC or RV. \\
(5) Place the mouthpiece between lips \\
horizontally or vertically and inhale deeply \\
and forcefully. \\
(6) Hold breath in full inspiration for 5-10 s \\
and exhale.
\end{tabular}

\section{Chopra et al ${ }^{21}$}

García-Cárdenas et al ${ }^{22}$

Epstein et al ${ }^{23}$
(1) Remove the cover.

(2) Turn the bottom clockwise until it clicks while keeping the inhaler upright.

(3) Turn the bottom counterclockwise to the maximum while keeping the inhaler upright.

(4) Turn your head away from the inhaler and exhale to FRC or RV.

(5) Place the mouthpiece between your lips horizontally or vertically and inhale deeply and forcefully.

(6) Hold your breath in full inspiration for $5-10 \mathrm{~s}$ and exhale.

1) Unscrew and lift off the cover.

(2) Hold the inhaler upright.

(3) Twist the red grip fully to the right as far as it will go and twist it back again to the left. A click will be heard.

(4) Breathe out gently taking care not to breathe into the Turbuhaler.

(5) Place the mouthpiece between teeth and lips.

(6) Inhale forcefully and deeply.

(7) Remove the inhaler from your mouth, hold breath for $8 \mathrm{~s}$, and exhale away from the mouthpiece.

(8) If further doses are needed, wait $30 \mathrm{~s}$ and repeat steps $2-7$.

(9) Replace white cap.

(10) Rinse your mouth with water. Do not swallow.

(1) Remove the cover before the first puff.

(2) Do not shake the inhaler.

(3) Hold the inhaler upright for priming.

(4) Turn the wheel correctly to the right.

(5) Turn the wheel correctly to the left until there is a click.

(6) Breath out.

(7) Breath away from the inhaler prior to inhalation.

(8) Put the mouthpiece between lips.

(9) Breath in deeply.

(10) Breath forcefully through your mouth.

(11) Remove the inhaler from your mouth.

(12) Hold breath for $>5 \mathrm{~s}$ before exhaling.

(14) Replace the cover after the second puff.
Stated Sources

(1) Put your thumb on the thumb grip and push the grip away from you as far as it will go until the mouthpiece appears and snaps into position.

(2) Slide the lever away from you as far as it will go until it clicks while keeping the Diskus horizontal.

(3) Holding the Diskus horizontally and away from your mouth, breathe out to FRC or RV

(4) Put the mouthpiece to your lips and breath in steadily and deeply.

(5) Remove the Diskus from your mouth. Hold breath in full inspiration for 5-10 s and exhale.

(6) Put your thumb on the grip and slide the thumb grip back towards you as far as it will go to click it shut.

(1) Put the thumb of your hand on the thumb grip and push your thumb away from you as far as it will go until the mouthpiece appears and snaps into position.

(2) Slide the lever away from you as far as it will go until it clicks while keeping the Diskus horizontal.

(3) Holding the Diskus horizontally and away from your mouth, breathe out to FRC or RV.

(4) Put the mouthpiece to your lips and breathe in steadily and deeply.

(5) Remove the Diskus from your mouth. Hold your breath in full inspiration for 5-10 $\mathrm{s}$ and exhale.

(6) Put your thumb on the thumb grip and slide the thumb grip back towards you as far as it will go to click it shut.

Spanish guidelines for asthma management
Manufacturers' instructions \\ instructions}
Manufacturers' recommendations and based on previous studies by Hanania et $\mathrm{al}^{24}$ and Kesten et $\mathrm{al}^{25}$




\section{Checklists for Powder Inhaler Technique}

Table 1. Continued

\begin{tabular}{|c|c|c|c|}
\hline Authors/Manufacturer & Turbuhaler Instructions & Diskus Instructions & Stated Sources \\
\hline Hanania et $\mathrm{al}^{24}$ & $\begin{array}{l}\text { (1) Remove the cover. } \\
\text { (2) Hold the inhaler upright. } \\
\text { (3) Turn the bottom clockwise and then } \\
\text { counterclockwise. } \\
\text { (4) Exhale away from inhaler to FRC or RV. } \\
\text { (5) Insert the mouthpiece between lips. } \\
\text { (6) Breathe in forcefully and deeply. } \\
\text { (7) Do not exhale. Remove the inhaler from } \\
\text { your mouth. } \\
\text { (8) Hold breath to comfort (5-10 s). } \\
\text { (9) Exhale. Wait } 20-30 \text { s before a second } \\
\text { inhalation. } \\
\text { (10) Hold upright. } \\
\text { (11) Rotate bottom again before a second } \\
\text { inhalation. }\end{array}$ & & $\begin{array}{l}\text { Not stated } \\
\text { (justifications } \\
\text { given) }\end{array}$ \\
\hline Kamps et al ${ }^{26}$ & $\begin{array}{l}\text { (1) Rotate the Turbuhaler counterclockwise and } \\
\text { back while keeping it upright. } \\
\text { (2) Place the mouthpiece between teeth and } \\
\text { lips. } \\
\text { (3) Inhale forcefully and deeply. }\end{array}$ & $\begin{array}{l}\text { (1) Open the Diskus and push the handle back } \\
\text { completely. } \\
\text { (2) Place the mouthpiece between teeth and } \\
\text { lips. } \\
\text { (3) Inhale forcefully and deeply. }\end{array}$ & $\begin{array}{l}\text { Netherlands Asthma } \\
\text { Foundation }\end{array}$ \\
\hline Kesten et $\mathrm{a}^{25}$ & $\begin{array}{l}\text { (1) Remove the cover. } \\
\text { (2) Hold the inhaler upright. } \\
\text { (3) Turn the bottom completely to the right and } \\
\text { then left until a click is heard. } \\
\text { (4) Exhale away from inhaler to FRC or RV. } \\
\text { (5) Put the mouthpiece between lips. } \\
\text { (6) Breathe in forcefully and deeply. } \\
\text { (7) Do not exhale. Remove the inhaler from } \\
\text { your mouth. } \\
\text { (8) Hold breath according to comfort. } \\
\text { (9) Exhale. Wait a minimum of } 20-30 \text { s before } \\
\text { second inhalation. } \\
\text { (10) Hold upright. } \\
\text { (11) Rotate the bottom correctly. }\end{array}$ & & $\begin{array}{l}\text { Not stated } \\
\text { (justifications } \\
\text { given) }\end{array}$ \\
\hline Khassawneh et $\mathrm{al}^{27}$ & $\begin{array}{l}\text { (1) Unscrew and lift off the cover. } \\
\text { (2) Hold the inhaler upright with the grip } \\
\text { downwards. } \\
\text { (3) Turn the grip until it clicks. } \\
\text { (4) Breathe in rapidly and deeply. }\end{array}$ & $\begin{array}{l}\text { (1) Open the device. } \\
\text { (2) Slide the lever until it clicks. } \\
\text { (3) Breathe in rapidly and deeply. }\end{array}$ & $\begin{array}{l}\text { Checklist derived } \\
\text { from medication } \\
\text { leaflet and previous } \\
\text { studies }^{28-30}\end{array}$ \\
\hline Lareau and Hodder ${ }^{31}$ & $\begin{array}{l}\text { Steps to prepare for inhalation after } \\
\text { unscrewing/removing/opening the cap: } \\
\text { (1) Twist the grip as far as possible in one } \\
\text { direction. } \\
\text { (2) Twist the grip back until it clicks. } \\
\text { Other steps given as critical errors: } \\
\text { Failure to remove cap } \\
\text { Holding inhaler upside down } \\
\text { Failure to load dose } \\
\text { Blowing into device } \\
\text { Failure to make tight seal with lips } \\
\text { Inhalation too weak or too slow }\end{array}$ & & $\begin{array}{l}\text { Checklist derived } \\
\text { from instructions in } \\
\text { package inserts and } \\
\text { adapted from } \\
\text { previous work }{ }^{32}\end{array}$ \\
\hline Lenney et al ${ }^{29}$ & $\begin{array}{l}\text { (1) Remove the mouthpiece cover. } \\
\text { (2) Prime inhaler by twisting the base until it } \\
\text { clicks with device vertical } \pm 45^{\circ} \text {. } \\
\text { (3) Breathe out gently. } \\
\text { (4) Place the inhaler between lips and breathe } \\
\text { in quickly and deeply until full. } \\
\text { (5) Hold breath for } 10 \mathrm{~s} \text {. }\end{array}$ & $\begin{array}{l}\text { (1) Rotate the cover to expose the mouthpiece. } \\
\text { (2) Prime the device by pushing the lever back } \\
\text { until it pops. } \\
\text { (3) Continue as for the Turbuhaler. }\end{array}$ & $\begin{array}{l}\text { Not stated } \\
\text { (justifications } \\
\text { given) }\end{array}$ \\
\hline
\end{tabular}




\section{Checklists for Powder Inhaler Technique}

Table 1. Continued

\begin{tabular}{|c|c|c|c|}
\hline Authors/Manufacturer & Turbuhaler Instructions & Diskus Instructions & Stated Sources \\
\hline Melani et al ${ }^{33}$ & $\begin{array}{l}\text { (1) Remove the cover. } \\
\text { (2) Hold the inhaler upright. } \\
\text { (3) Load the dose. } \\
\text { (4) Place the mouthpiece between lips. } \\
\text { (5) Inhale by mouth. } \\
\text { (6) Breathe out the device mouthpiece. } \\
\text { (7) Inhale deeply and quickly. } \\
\text { (8) Breathe forcefully and deeply. } \\
\text { (9) Hold breath. } \\
\text { (10) Breathe out the device mouthpiece. }\end{array}$ & $\begin{array}{l}\text { (1) Turn the cover. } \\
\text { (2) Load the dose. } \\
\text { (3) Inhale by mouth. } \\
\text { (4) Breathe out the device mouthpiece. } \\
\text { (5) Inhale deeply and quickly. } \\
\text { (6) Place the mouthpiece between your lips. } \\
\text { (7) Inhale forcefully and deeply. } \\
\text { (8) Hold breath. } \\
\text { (9) Breathe out the device mouthpiece. }\end{array}$ & $\begin{array}{l}\text { Checklist translated } \\
\text { from the original } \\
\text { Italian format in a } \\
\text { supplementary data } \\
\text { file prepared by the } \\
\text { Educational Group } \\
\text { members }\end{array}$ \\
\hline Melani et $\mathrm{al}^{34}$ & $\begin{array}{l}\text { (1) Remove the cap correctly. } \\
\text { (2) Load successfully. } \\
\text { (3) Hold the device upright. } \\
\text { (4) After loading, never exhale through the } \\
\text { mouthpiece. } \\
\text { (5) Exhale to RV before inhalation. } \\
\text { (6) Place the mouthpiece into the mouth, } \\
\text { sealing the lips. } \\
\text { (7) Inhale forcefully. } \\
\text { (8) Inhale by mouth and not by nose. } \\
\text { (9) Continue to inhale for as long as possible. } \\
\text { (10) Hold breath for } 4-6 \text { s/hold breath for } \\
8-10 \text { s. } \\
\text { (11) Never exhale into the mouthpiece after } \\
\text { inhalation. } \\
\text { (12) Replace the mouthpiece cover. }\end{array}$ & $\begin{array}{l}\text { (1) Correctly remove the cap. } \\
\text { (2) Load successfully. } \\
\text { (4) After loading, never exhale through the } \\
\text { mouthpiece. } \\
\text { (5) Exhale to RV before inhalation. } \\
\text { (6) Place the mouthpiece into the mouth, } \\
\text { sealing the lips. } \\
\text { (7) Inhale forcefully. } \\
\text { (8) Inhale by mouth and not by nose. } \\
\text { (9) Continue to inhale for as long as possible. } \\
\text { (10) Hold breath for } 4-6 \text { s/hold breath for } \\
8-10 \text { s. } \\
\text { (11) Replace the mouthpiece cover. }\end{array}$ & $\begin{array}{l}\text { Global Initiative for } \\
\text { Asthma guidelines, } \\
\text { Global Initiative for } \\
\text { Chronic } \\
\text { Obstructive Lung } \\
\text { Disease Executive } \\
\text { Committee, and } \\
\text { manufacturers' } \\
\text { instructions }\end{array}$ \\
\hline Molimard et al ${ }^{28}$ & $\begin{array}{l}\text { (1) Hold the inhaler upright (tolerance of } \\
\pm 45^{\circ} \text { ). } \\
\text { (2) Rotate the grip and back until it clicks. } \\
\text { (3) Exhale before inhalation. } \\
\text { (4) Exhale away from the mouthpiece. } \\
\text { (5) Inhale through the mouthpiece. } \\
\text { (6) Hold breath a few seconds. }\end{array}$ & $\begin{array}{l}\text { (1) Hold the mouthpiece towards you. } \\
\text { (2) Slide the lever as far as possible. } \\
\text { (3) Exhale before inhalation. } \\
\text { (4) Exhale away from the mouthpiece. } \\
\text { (5) Inhale through the mouthpiece. } \\
\text { (6) Hold breath a few seconds. }\end{array}$ & $\begin{array}{c}\text { Manufacturers' } \\
\text { instructions }\end{array}$ \\
\hline Moore and Stone ${ }^{35}$ & $\begin{array}{l}\text { (1) Correctly remove the cap. } \\
\text { (2) Load successfully. } \\
\text { (3) Hold the device upright. } \\
\text { (4) After loading, never exhale through the } \\
\text { mouthpiece. } \\
\text { (5) Exhale to RV before inhalation. } \\
\text { (6) Place the mouthpiece into the mouth, } \\
\text { sealing the lips. } \\
\text { (7) Inhale forcefully. } \\
\text { (8) Inhale by mouth and not by nose. } \\
\text { (9) Continue to inhale for as long as possible. } \\
\text { (10) Hold breath for } 4-6 \text { s/hold breath for } 8- \\
10 \text { s/do not hold breath. } \\
\text { (11) Never exhale into the mouthpiece after } \\
\text { inhalation. } \\
\text { (12) Replace the mouthpiece cover. }\end{array}$ & $\begin{array}{l}\text { (1) Correctly remove the cap } \\
\text { (2) Loading successfully. } \\
\text { (4) After loading, never exhale through the } \\
\text { mouthpiece. } \\
\text { (5) Exhale to RV before inhalation. } \\
\text { (6) Place the mouthpiece into the mouth, } \\
\text { sealing the lips. } \\
\text { (7) Inhale forcefully. } \\
\text { (8) Inhale by mouth and not by nose. } \\
\text { (9) Continue to inhale for as long as possible. } \\
\text { (10) Hold breath for } 4-6 \text { s/hold breath for } 8- \\
10 \text { s/do not hold breath. } \\
\text { (11) Replace the mouthpiece cover. }\end{array}$ & Not stated \\
\hline Nelson et $\mathrm{al}^{36}$ & & $\begin{array}{l}\text { (1) Open the inhaler. } \\
\text { (2) Push the lever. } \\
\text { (3) Keep the inhaler level and flat (after the } \\
\text { dose is activated). } \\
\text { (4) Exhale (away from the mouthpiece). } \\
\text { (5) Put the mouthpiece in your mouth. } \\
\text { (6) Keep the inhaler level and flat (while } \\
\text { inhaling). } \\
\text { (7) Inhale through your mouth. } \\
\text { (8) Inhale quickly and deeply. } \\
\text { (9) Hold breath. } \\
\text { (10) Exhale (away from the mouthpiece). } \\
\text { (11) Close the inhaler. }\end{array}$ & $\begin{array}{l}\text { FDA-approved } \\
\text { product package } \\
\text { inserts and } \\
\text { American College } \\
\text { of Chest Physicians } \\
\text { guidelines }\end{array}$ \\
\hline
\end{tabular}




\section{Checklists for Powder Inhaler Technique}

Table 1. Continued

\begin{tabular}{|c|c|c|c|}
\hline Authors/Manufacturer & Turbuhaler Instructions & Diskus Instructions & Stated Sources \\
\hline Nimmo et al ${ }^{37}$ & $\begin{array}{l}\text { (1) Remove the mouthpiece cover. } \\
\text { (2) Hold the device upright. } \\
\text { (3) Load the dose. } \\
\text { (4) Twist the grip back to the original position. } \\
\text { (5) Exhale fully. } \\
\text { (6) Place the mouthpiece between teeth and lips. } \\
\text { (7) Breathe in through the Turbuhaler quickly and } \\
\text { deeply. } \\
\text { (8) Hold breath for } 10 \mathrm{~s} \text {. } \\
\text { (9) Breath out slowly. }\end{array}$ & & $\begin{array}{l}\text { Not stated } \\
\text { (justifications } \\
\text { given) }\end{array}$ \\
\hline Rönmark et al ${ }^{38}$ & $\begin{array}{l}\text { (1) Release the dose (ie, hold the inhaler in the } \\
\text { correct position). } \\
\text { (2) Correctly releasing one dose. } \\
\text { (3) Exhale before use. } \\
\text { (4) Exhale away from the mouthpiece before } \\
\text { inhalation. } \\
\text { (5) Seal lips tightly around the mouthpiece. } \\
\text { (6) Inhale. } \\
\text { (7) Hold breath after inhalation. } \\
\text { (9) Exhale away from the mouthpiece after } \\
\text { inhalation. }\end{array}$ & & $\begin{array}{l}\text { Manufacturers' } \\
\text { instructions, with } \\
\text { justifications of } \\
\text { highlighted steps } \\
\text { (self-medication } \\
\text { steps) given }\end{array}$ \\
\hline Rootmensen et al ${ }^{39}$ & $\begin{array}{l}\text { (1) Keep inhaler in upright position. } \\
\text { (2) Twist the grip to the right and twist back until } \\
\text { it clicks. } \\
\text { (3) Place inhaler in horizontal position. } \\
\text { (4) Sit upright or stand. } \\
\text { (5) Breathe out to RV. } \\
\text { (6) Tilt head back (hyperextend). } \\
\text { (7) Close lips on inhaler. } \\
\text { (8) Inhale forcefully and deeply. } \\
\text { (9) Hold breath for at least } 5 \text { s. } \\
\text { (10) Breathe out away from the mouthpiece. }\end{array}$ & $\begin{array}{l}\text { (1) Activate the inhaler. } \\
\text { (2) Sit upright or stand. } \\
\text { (3) Breathe out to RV. } \\
\text { (4) Tilt head back (hyperextend). } \\
\text { (5) Close lips on inhaler. } \\
\text { (6) Inhale forcefully and deeply. } \\
\text { (7) Hold breath for at least } 5 \mathrm{~s} \text {. } \\
\text { (8) Breathe out away from the mouthpiece. }\end{array}$ & $\begin{array}{l}\text { Based on van } \\
\text { Beerendonk et al }{ }^{40} \\
\text { and van der } \\
\text { Palen } 18 ; \text { scoring } \\
\text { system agreed on } \\
\text { by } 3 \text { investigators }\end{array}$ \\
\hline Serra-Batlles et al ${ }^{41}$ & $\begin{array}{l}\text { (1) Remove the cover. } \\
\text { (2) Keep the device upright. } \\
\text { (3) Twist the grip forward. } \\
\text { (4) Twist the grip backward. } \\
\text { (5) Put to mouth. } \\
\text { (6) Breath from the inhaler. } \\
\text { (7) Replace the cover and close the device. }\end{array}$ & $\begin{array}{l}\text { (1) Open the inhaler. } \\
\text { (2) Slide the lever. } \\
\text { (3) Put to your mouth. } \\
\text { (4) Breathe in the inhaler. } \\
\text { (5) Close the device. }\end{array}$ & Not stated \\
\hline Sestini et al ${ }^{42}$ & $\begin{array}{l}\text { (1) Open the device. } \\
\text { (2) Load the device. } \\
\text { (3) Keep the inhaler }<45^{\circ} \text { from the vertical axis } \\
\text { during loading. } \\
\text { (4) Exhale away from the mouthpiece of the } \\
\text { device after loading. } \\
\text { (5) Seal the lips around the mouthpiece during } \\
\text { inhalation. } \\
\text { (6) Inhale to total lung capacity. } \\
\text { (7) Inhale by mouth and not by nose. } \\
\text { (8) Exhale away from the mouthpiece of the } \\
\text { device after inhalation. } \\
\text { (9) Hold breath after inhalation. } \\
\text { (10) Close the device properly. }\end{array}$ & $\begin{array}{l}\text { (1) Open the device. } \\
\text { (2) Load the device. } \\
\text { (3) Exhale away from the mouthpiece of the } \\
\text { device after loading. } \\
\text { (4) Seal your lips around the mouthpiece during } \\
\text { inhalation. } \\
\text { (5) Inhale to total lung capacity. } \\
\text { (6) Inhale by mouth and not by nose. } \\
\text { (7) Hold breath after inhalation. } \\
\text { (8) Close the device properly. }\end{array}$ & $\begin{array}{c}\text { Manufacturers' } \\
\text { instructions }\end{array}$ \\
\hline Sleath et a ${ }^{43}$ & $\begin{array}{l}\text { (1) Lift off white cover to reveal the mouthpiece. } \\
\text { (2) Hold the device with the mouthpiece up and } \\
\text { twist the grip at the base back and forth one } \\
\text { time to load the dose. } \\
\text { (3) Hold the device horizontally and exhale gently } \\
\text { away from the mouthpiece. } \\
\text { (4) Place the mouthpiece between lips. } \\
\text { (5) Take a forceful breath in steadily and deeply. } \\
\text { (6) Hold breath for } 10 \mathrm{~s} \text {. } \\
\text { (7) Replace the white cover. }\end{array}$ & $\begin{array}{l}\text { (1) Open the device until it clicks. } \\
\text { (2) To load a dose, hold the device horizontally } \\
\text { and slide the lever away from you until it } \\
\text { stops (there should be a second click). } \\
\text { (3) Exhale gently away from the mouthpiece. } \\
\text { (4) Place the mouthpiece between your lips. } \\
\text { (5) Take a forceful breath in steadily and } \\
\text { deeply. } \\
\text { (6) Hold breath for } 10 \mathrm{~s} \text {. } \\
\text { (7) Close the device by sliding the thumb grip } \\
\text { towards you until it clicks. }\end{array}$ & Not stated \\
\hline
\end{tabular}


Table 1. Continued

\begin{tabular}{|c|c|c|c|}
\hline Authors/Manufacturer & Turbuhaler Instructions & Diskus Instructions & Stated Sources \\
\hline Steier et al ${ }^{44}$ & $\begin{array}{l}\text { (1) Open the cap. } \\
\text { (2) Hold the device vertically. } \\
\text { (3) Screw the wheel. } \\
\text { (4) Screw the wheel back until you hear a } \\
\text { click. } \\
\text { (5) Exhale deeply. } \\
\text { (6) Put the mouthpiece into your mouth. } \\
\text { (7) Inhale deeply and strongly. } \\
\text { (8) Hold the breath. } \\
\text { (9) Close the cap. }\end{array}$ & & Not stated \\
\hline van Beerendonk et $\mathrm{al}^{40}$ & $\begin{array}{l}\text { (1) Prepare the inhaler before usage. } \\
\text { (2) Keep inhaler horizontal. } \\
\text { (3) Exhale to RV. } \\
\text { (4) Place the mouthpiece between lips and } \\
\text { teeth. } \\
\text { (5) Inhale forcefully and deeply. } \\
\text { (6) Take inhaler out of your mouth. } \\
\text { (7) Hold breath for } 5 \text { s. } \\
\text { (8) Exhale and repeat from step } 3 .\end{array}$ & & $\begin{array}{l}\text { Netherlands Asthma } \\
\text { Foundation }\end{array}$ \\
\hline van der Palen et al ${ }^{18}$ & $\begin{array}{l}\text { (1) Remove the cap from the inhaler. } \\
\text { (2) Keep the inhaler upright. } \\
\text { (3) Rotate the grip until it clicks. } \\
\text { (4) Exhale to RV. } \\
\text { (5) Exhale away from the mouthpiece. } \\
\text { (6) Place the mouthpiece between teeth and } \\
\text { lips. } \\
\text { (7) Inhale forcefully and deeply. } \\
\text { (8) Hold breath for } 5 \mathrm{~s} \text {. } \\
\text { (9) Exhale away from the mouthpiece. } \\
\text { (10) Replace the cap. }\end{array}$ & $\begin{array}{l}\text { (1) Open the inhaler. } \\
\text { (2) Push the lever back completely. } \\
\text { (3) Exhale to RV. } \\
\text { (4) Exhale away from the mouthpiece. } \\
\text { (5) Place the mouthpiece between teeth and } \\
\text { lips. } \\
\text { (6) Inhale forcefully and deeply. } \\
\text { (7) Hold breath for } 5 \mathrm{~s} \text {. } \\
\text { (8) Exhale away from the mouthpiece. } \\
\text { (9) Close the inhaler. }\end{array}$ & $\begin{array}{l}\text { Netherlands Asthma } \\
\text { Foundation }\end{array}$ \\
\hline \multicolumn{4}{|c|}{$\begin{array}{l}\text { Steps shown in italics are those stated by the authors to be important, essential, or critical. } \\
\text { * AstraZeneca (http://xpil.medicines.org.uk/viewpil.aspx?docid=14249), Accessed June 6, 2014) } \\
\dagger \text { GlaxoSmithKline (https://www.gsksource.com/gskprm/htdocs/documents/ADVAIR-DISKUS-PI-MG.PDF), Accessed June 6, 2014) } \\
\text { FRC = functional residual capacity } \\
\text { RV = residual volume }\end{array}$} \\
\hline
\end{tabular}

Diskus). Some checklists also included an item for waiting a specified time between doses, ${ }^{22,24,25}$ and one included rinsing and spitting out after use of the inhaler. ${ }^{22}$

Some checklists (10 for the Turbuhaler and 6 for the Diskus) further identified a subset of steps as being essential or critical; these are indicated in italics in Table 1. The number of these essential steps varied, most commonly 4 for the Turbuhaler and 3 for the Diskus. For the Turbuhaler, the essential steps were usually holding the device upright during loading, twisting the base around and back to load a dose, exhaling away from the device, and inhaling strongly and forcefully. For the Diskus, the most common essential steps were opening the mouthpiece, pushing the lever to load a dose, and inhaling. However, the essential items varied substantially between checklists. In most cases, the authors stated that the selection of an item as essential or critical was based on their evaluation that if this step was incorrectly performed, little or no medication would reach the lungs.
Other authors classified some steps as common problem steps. ${ }^{36}$ van Beerendonk et $\mathrm{al}^{40}$ divided the checklist into skilled and non-skilled items, stating that non-skilled items, such as exhaling to residual volume, required only information, whereas skilled items, such as inhaling forcefully and deeply, also required physical training.

\section{Scoring and Reporting Systems for Inhaler Technique Checklists}

As with checklist items, scoring systems varied greatly between publications. The most common approach was to give a score of 1 for each correctly/satisfactorily performed step and a score of 0 for each skipped or incorrectly/ unsatisfactorily performed step. ${ }^{14,20,22,24,36,41,44}$ Kesten et al ${ }^{25}$ graded pharmacists' Turbuhaler skills as good, fair, adequate, or skipped, with a score of 0 for skipped/not adequate and a score of 1 for good/fair. Rönmark et al ${ }^{38}$ allocated a score of 2 for correct, 1 for not completely correct, and 0 for incorrect. 
Some checklists had a more complicated scoring system. Steier et $\mathrm{al}^{44}$ gave a total score of 0 if a step was left out that was necessary for successful inhalation (eg, opening of the cap, loading) or if the patient exhaled into the device, and all other attempts were rated from 1-9 points. Sestini et $\mathrm{al}^{42}$ gave a score of 1 for each item of the checklist considered as minor and a score of 3 for each one considered as major.

For reporting a patient's overall inhaler technique, most authors reported the inhaler technique score as the sum of the scores for each step, or as the proportion of checklist items that were performed correctly. More complicated systems were used by some authors. Rönmark et al ${ }^{38}$ assigned overall correct use of the device if no step was performed incorrectly (score of 0 ) and if no more than 2 of 4 specific steps (steps 2, 3, 5, and 7 in Table 1) were not completely correct (score of 1 ). Lenney et al ${ }^{29}$ provided 3 checklists for each device: the first (A, called Optimal Technique) included all steps required to use the device correctly, the second (B, called Some Delivery) included 2-3 common errors relevant to the device, and the third (C, called Little or No Delivery) included more substantial errors. Each patient's technique was graded as A, B, or C according to the checklist to which it best corresponded.

For summarizing population results, the most common approaches were to report the average per-patient score and/or the proportion of patients who demonstrated all checklist steps correctly or who had any errors. ${ }^{18,43,46,47}$ van der Palen et $\mathrm{al}^{18}$ and Basheti et al ${ }^{19,46,47}$ also reported the proportion of patients with correct essential technique (all essential steps in Table 1 correct), and Melani et al ${ }^{33}$ reported the proportion of patients with any critical errors. Some authors also reported data for each individual checklist step, reporting the proportion of patients performing each step correctly ${ }^{43}$ or incorrectly..$^{33}$

\section{Source of Information for Checklists}

It was not always possible to determine the source of a published checklist (Table 1). Authors often stated that they had based their checklists on the manufacturers' leaflets, ${ }^{20,21,28,38,42}$ previously published checklists, ${ }^{23,31}$ or national and international asthma foundation guidelines ${ }^{18,22}$ and/or that they developed their own. Personal or expert opinion was often used to justify the checklist items; for example, Nimmo et al $^{37}$ stated that the Turbuhaler checklist steps were those "identified as necessary for correct inhalation technique for the purpose of the study."

\section{Summary}

The above body of literature demonstrates that there is no defined standard for assessment of inhaler technique with the Turbuhaler or Diskus with regard to the number and content of steps in the relevant checklists. Not all studies stated the source of their checklists, and even when the source of the checklists was stated, there were many different sources. Scoring systems used to present the results of the assessments were very different as well, making it unfeasible to compare the results in many cases. Therefore, although overall similar processes are described in each checklist, the range of content and format presents a challenge with regard to drawing comparisons between the checklists and validation of the individual steps.

A recent review has called for standardization of the way inhaler device studies are conducted and the way they are reported to physicians and health authorities. ${ }^{48}$ Considering the above findings, there are several obvious questions at this stage. Which checklists are most appropriate to be used for future studies assessing and/or educating patients on correct Turbuhaler and/or Diskus technique? Which steps should be weighed more, that is, which steps can be considered essential steps? How should inhaler technique data be scored and reported? To answer these questions, we examined evidence for the clinical importance of each of the steps commonly included in checklists for the Turbuhaler and Diskus.

\section{Evidence for Inclusion of Individual Technique Steps in Device Checklists}

Each checklist deals with 3 overall processes: preparation of the device/loading of the dose, delivery of the dose, and preparation of the device for storage. Within these 3 overall processes, we identified published evidence that supports individual checklist steps. It is not possible to find evidence for some of the steps that are included in the manufacturers' instructions for a particular device; these recommendations may have been developed in-house, with various options tested and some perhaps abandoned, and the evidence is not necessarily available in the public domain.

Preparation of the Device. Most checklists describe the preparation of the device to include (1) removing the cover (Turbuhaler) or opening the cover (Diskus) and (2) loading a dose for delivery.

(1) Although there is no published evidence on the importance, necessity, or impact of removing the cover (Turbuhaler) or opening the cover (Diskus), the design of the devices means that it would be physically impossible for any medication to be delivered if this step was not performed. This may seem so obvious as to be unnecessary to check, but a small proportion of patients fail to complete this step. ${ }^{34}$

(2) Loading (or preparing) a dose for delivery is described for both the Turbuhaler and Diskus. For the Turbuhaler (see Fig. 1), the medication powder is stored in 
bulk in a reservoir (storage unit for drug), above a dose well (dosing unit), and prior to drug administration, a single dose of power needs to be aliquoted (loaded). ${ }^{49}$ This is achieved by holding the device upright and rotating the grip at the base of the Turbuhaler in one direction and back again. Although early Turbuhaler instructions specified starting with a counterclockwise rotation, the manufacturer later clarified that the direction of initial rotation was irrelevant provided the base was rotated in both directions, and a click was heard. If the device is upright, the drug falls by gravity from the reservoir into the dosing unit, and excess powder is scraped off to make the measured dose available. $6,50,51$ This is an important step because, without it, an appropriate dose of medication will not be available for delivery.

In contrast, the Diskus contains a coiled strip containing metered doses of powder (see Fig. 2). When the lever is pulled to the right, the 2 foil strips are peeled apart, and the dose is aligned with and exposed to the mouthpiece. Without the lever being pulled across, it is physically impossible for any medication to be inhaled.

Delivery of the Dose. This process involves all of the breathing maneuvers required to move the drug from the device and into the body. Typically, the checklists involve a description of (1) how to exhale the air from the lungs (how much and where), (2) how to place the mouthpiece of the device into the mouth, (3) how to inhale the medication from the device, and (4) breath-holding after inhalation.

(1) Exhaling air prior to inhalation is a physiological process. Although some checklists do not include this step on the basis that it does not affect clinical outcomes, ${ }^{52}$ other checklists specify exhaling to residual volume, based on clinical experience that this ensures that the patient can make a deep and forceful inhalation. ${ }^{19,47}$ For both the Turbuhaler and Diskus, it is important to exhale away from the mouthpiece, as there is evidence that exhalation into the device may reduce the dose delivered to the lung. ${ }^{53-55}$ Exhalation into or near the device compromises the integrity of the powder dose: for both the Turbuhaler ${ }^{12,49,51,53,56,57}$ and the Diskus, ${ }^{58}$ it can displace the already loaded dose of powder and introduce moisture, potentially causing aggregation of powder particles.

(2) Placing the mouthpiece between teeth and lips before inhalation (Turbuhaler and Diskus) may also influence clinical outcomes. ${ }^{58} \mathrm{~A}$ tight seal between the lips and mouthpiece avoids air leakage, which would otherwise reduce the inspiratory flow. Placing the mouthpiece past the lips and teeth is important; otherwise, a portion of the aerosol particles may deposit onto the teeth and tongue, decreasing the amount of medication reaching the lungs. ${ }^{58}$

(3) Inhaling forcefully and deeply (ie, generating sufficient inspiratory flow) has been shown to be important for optimal drug delivery for the Turbuhaler and Diskus, ${ }^{6,29,59}$ as it ensures de-aggregation of the metered dose ${ }^{60}$ and deep lung deposition. ${ }^{58,61}$ Inspiration should be forceful from the beginning of inhalation rather than increasing gradually. ${ }^{57}$ Failure to do so results in partial delivery of the medication to the lungs ${ }^{29}$ and increased drug deposition in the mouth and pharynx. ${ }^{57,60,62,63}$ Maintaining a forceful and deep inhalation from the start of the inhalation maneuver and for as long as possible ensures that most patients can use a powder inhaler (Turbuhaler and Diskus) irrespective of the resistance of the device or their disease severity. ${ }^{64}$ However, although most patients can achieve the required flow, ${ }^{65,66}$ flow is more likely to be a problem for the Turbuhaler than for the lower resistance Diskus. ${ }^{67,68}$

(4) Breath-holding following inhalation (Turbuhaler and Diskus) is included in most of the published checklists and the Global Initiative for Asthma web site checklists for both the Turbuhaler and the Diskus (www.ginasthma. org/Turbohaler; www.ginasthma.org/Accuhaler-(Diskus), Accessed June 6, 2014). This is one of the most frequently discussed items in inhaler technique checklists. ${ }^{52}$ Although the manufacturer's instructions for the Turbuhaler do not include this step, many clinicians advise inclusion of a breath-hold for powder inhalers to avoid confusion with pressurized metered-dose inhalers, for which a breath-hold is necessary. ${ }^{69}$ For pressurized metered-dose inhalers, the original suggestion of a 10-s breath-hold was based on lung deposition studies, ${ }^{69}$ but the general recommendation for clinical practice is that the breath should be held only as long as is comfortable. A 5-s breath-hold is a realistic target for most patients. ${ }^{70}$

Preparation of the Device for Storage. Replacing the cap after use of a Turbuhaler or closing the lid of the Diskus is the final step articulated in inhaler checklists. Although this step is post-drug delivery, it serves to keep the device clean, prevent foreign objects from entering the mouthpiece, and minimize absorption of moisture from the ambient environment. ${ }^{58,71}$ Therefore these steps are important in maintaining the drug integrity for subsequent doses. For the Turbuhaler, replacing the cap is included in the manufacturer's instructions but in fewer than half of published Turbuhaler checklists.

\section{Evidence for Additional Steps}

There does not appear to be any published evidence to support a 30-s delay between doses, and it is not included in manufacturers' instruction leaflets in countries such as Jordan, Canada, Australia, and the United States. This step would only be relevant to patients prescribed 2 or more inhalation doses on each occasion. Likewise, an instruction to rinse the mouth after taking a dose, although important for patients using inhaled corticosteroids to reduce 
Table 2. Recommended Checklists for Assessment of Turbuhaler and Diskus Technique

\begin{tabular}{ll}
\hline \multicolumn{1}{c}{ Checklist for Turbuhaler Technique } & Checklist for Diskus Technique \\
\hline (1) Remove the cap from the inhaler. & (1) Open the inhaler. \\
(2) Keep the inhaler upright. & (2) Push the lever back completely. \\
(3) Rotate the grip counterclockwise and then back until a click is heard. & (3) Exhale to RV. \\
(4) Exhale to RV. & (4) Exhale away from the mouthpiece. \\
(5) Exhale away from the mouthpiece. & (5) Place the mouthpiece between teeth and lips. \\
(6) Place the mouthpiece between teeth and lips. & (6) Inhale forcefully and deeply. \\
(7) Inhale forcefully and deeply. & (7) Hold breath for 5 s. \\
(8) Hold breath for $5 \mathrm{~s}$. & (8) Exhale away from the mouthpiece. \\
(9) Exhale away from the mouthpiece.* & (9) Close the inhaler.
\end{tabular}

Essential steps (ie, if not performed correctly by the patients, little or no medication would reach the lungs) are shown in italics.

* The patient should also, of course, replace the Turbuhaler cap after use. These published checklists were standardized to 9 items each to allow comparison of scores between the two devices. $\mathrm{RV}=$ residual volume

the risk of oropharyngeal side effects, is not relevant to those using the Turbuhaler or Diskus for delivery of shortor long-acting $\beta_{2}$ agonists.

Nevertheless, if the perspective of Appel ${ }^{13}$ is adopted, that is, the better the inhaler technique (the more correct steps performed) by the patient, the better the clinical response expected, ${ }^{14,47}$ these additional steps should be considered while delivering a complete Turbuhaler and Diskus technique education. Patients for whom a second dose or mouth rinsing is relevant may need to be asked about these steps, as they may not think to perform them when asked to demonstrate their technique.

\section{Essential Steps for the Turbuhaler and Diskus}

As mentioned previously, in some published checklists, a series of steps have been identified as essential. Considering the evidence above, it becomes clear that, without the completion of certain steps, it is unlikely that any medication will be delivered to the airways. It is these steps that could be considered essential. They include opening/removing the cover; loading the device, ${ }^{49}$ which, in the case of the Turbuhaler, should be completed while holding the device upright ${ }^{18,50}$; and inhaling through the mouthpiece forcefully and deeply. ${ }^{57,62}$ Failure to perform these steps will result in no medication being available because of the physical barrier of the cap or lid, the unavailability of the drug, or the drug failing to be transported out of the inhaler.

From the literature, the published checklists for the Turbuhaler and Diskus that best describe all of the steps recommended are those published by van der Palen et $\mathrm{al}^{18}$ and Basheti et al ${ }^{14}$ (Table 2).

\section{Reporting Turbuhaler/Diskus Technique Data}

To allow comparison of data from different studies, we recommend that inhaler technique data should be presented as (1) the proportion of patients with correct technique (all steps in the checklist correct); (2) the proportion of patients with correct essential technique (all essential steps identified in each checklist correct); (3) the mean \pm SD of inhaler technique scores; and (4) for more detailed studies, the proportion of patients with correct technique for each individual step in the technique checklist.

If all of these metrics are reported (or at least recommendations 1-3), appropriate comparison of populations will be possible in different locations and over time. In addition, the effectiveness of interventions designed to improve inhaler technique and thus clinical outcomes could be established.

\section{Clinical Impact of Using Inhaler Technique Checklists}

In the literature and in clinical practice, there is broad acceptance that poor inhaler technique is a substantial contributor to poor asthma control and to increased health care costs. ${ }^{49}$ For pressurized metered-dose inhalers, Giraud et $\mathrm{al}^{72}$ showed a strong relationship between poor technique, assessed with a standardized checklist, and a composite asthma instability index. A subsequent study by the same authors ${ }^{15}$ showed that assessment and correction of inhaler technique using a standardized checklist led to a significant improvement in asthma control, particularly in patients whose inhaler technique was suboptimal at the start. ${ }^{15}$ Although there have been many studies evaluating powder inhaler technique, a review by Lavorini et al ${ }^{56}$ found that few studies had documented the relationship between incorrect technique and clinical outcomes; however, there is no reason to suppose that this would be any different than for pressurized metered-dose inhalers. The concept of essential steps is supported by the finding of Melani et $\mathrm{al}^{33}$ that patients with one or more critical errors on the Turbuhaler or Diskus checklist had significantly 
worse asthma control, impaired quality of life, activity limitation, and sleep disturbance. The strongest confirmation of the value of inhaler checklists comes from studies in which inhaler assessment and skills training were associated with significantly improved asthma outcomes. ${ }^{14}$ Again, there are few studies, but in young children, Goren et $\mathrm{al}^{73}$ showed that improved Turbuhaler technique with a rudimentary child-specific checklist was associated with greater bronchodilator effect. In the 6-month study by Basheti et al, ${ }^{14}$ a brief pharmacy intervention, with assessment and correction of inhaler technique and checklistbased inhaler labels, led to significant improvement in asthma outcomes compared with a control group. In that study, changes in asthma control measures over time seemed to relate more to the proportion of patients with all steps correct than to average inhaler technique scores. ${ }^{14,47}$

Considering the difference in steps between Turbuhaler and Diskus checklists, another important practical recommendation that this review can add is that, where possible, only one type of inhaler device should be used per patient. Previous studies have shown that use of different devices predisposes patients to inhaler misuse compared with using only one type of inhaler. ${ }^{12,74,75}$ In addition, substituting a different powder inhaler for that previously used by the patient can cause confusion for the patient. ${ }^{76}$ Skilled health care professionals have an essential role in evaluating patients' inhalation technique and ensuring they are using the inhalers properly. ${ }^{12,57,68}$ Avoiding multiple inhaler devices for a patient can also lead to fewer steps to teach/learn and hence less confusion in demonstrating/performing the individual steps per inhaler device for health care professionals and patients.

\section{Conclusions}

Inhaler technique checklists have been used in the majority of studies investigating the inhaler technique performance of patients and of health care professionals such as pharmacists. This literature review demonstrated considerable heterogeneity in inhaler technique checklists for the same powder devices in different studies, which makes direct comparison of results difficult. This may cause confusion for both patients and health care professionals and ultimately contribute to poor technique. The issue of inhaler technique checklist heterogeneity was first raised more than a decade ago, ${ }^{16}$ but more work clearly needs to be done to ensure standardization of checklists for clinical and research contexts.

Checklists are feasible for use in clinical research and clinical practice, with no equipment costs and with minimal time required. Unlike existing inhaler technique assessment devices, which are able to check only some components of inhaler use, use of a checklist ensures that every step required for delivery of medication is assessed. How- ever, the differences between the various checklists and scoring systems in the literature make the direct comparison of results difficult and at times inappropriate. Hence, in this review, we have recommended checklists and scoring systems for the most commonly used powder inhalers, the Turbuhaler and Diskus, based on the literature and previous findings. If future studies in this area use common checklists and scoring systems, the problem of inhaler technique assessment heterogeneity between different studies will be resolved, allowing for more accurate comparisons between the results.

From the literature, the published checklists for the Turbuhaler and Diskus that best describe all of the steps recommended above are those published by van der Palen et al ${ }^{18}$ and Basheti et al. ${ }^{14}$ The validity of these checklists is supported by evidence for significant improvement in asthma outcomes when technique is assessed and improved..$^{14}$ It is recommended that future studies use these checklists so that direct comparison between studies can assess the efficacy of specific interventions.

\section{REFERENCES}

1. Kemp JP, Hill MR, Vaughan LM, Meltzer EO, Welch MJ, Ostrom NK. Pilot study of bronchodilator response to inhaled albuterol delivered by metered-dose inhaler and a novel dry powder inhaler. Ann Allergy Asthma Immunol 1997;79(4):322-326.

2. Richter K. Successful use of DPI systems in asthmatic patients-key parameters. Respir Med 2004;98(Suppl B):S22-S27.

3. Atkins PJ. Dry powder inhalers: an overview. Respir Care 2005; 50(10):1304-1312.

4. Roche N, Huchon GJ. Rationale for the choice of an aerosol delivery system. J Aerosol Med 2000;13(4):393-404.

5. Muller V, Gálffy G, Eszes N, Losonczy G, Bizzi A, Nicolini G, et al. Asthma control in patients receiving inhaled corticosteroid and long-

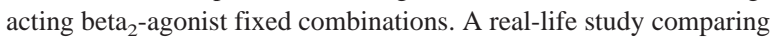
dry powder inhalers and a pressurized metered dose inhaler extrafine formulation. BMC Pulm Med 2011;11:40.

6. Wetterlin K. Turbuhaler: a new powder inhaler for administration of drugs to the airways. Pharm Res 1988;5(8):506-508.

7. Chrystyn H. The Diskus inhaler: A review of its pharmaceutical and clinical performance. Clin Drug Invest 1999;18(4):287-296.

8. Engel T, Heinig JH, Madsen F, Nikander K. Peak inspiratory flow and inspiratory vital capacity of patients with asthma measured with and without a new dry-powder inhaler device (Turbuhaler). Eur Respir J 1990;3(9):1037-1041.

9. Hawksworth GM, James L, Chrystyn H. Characterization of the inspiratory manoeuvre when asthmatics inhale through a Turbohaler pre- and post-counselling in a community pharmacy. Respir Med 2000;94(5):501-504.

10. Lavorini F, Levy ML, Corrigan C, Crompton G, ADMIT Working Group. The ADMIT series-issues in inhalation therapy. 6) Training tools for inhalation devices. Prim Care Respir J 2010;19(4):335-341.

11. Kamin WE, Genz T, Roeder S, Scheuch G, Cloes R, Juenemann R, Trammer $T$. The inhalation manager: a new computer-based device to assess inhalation technique and drug delivery to the patient. J Aerosol Med 2003;16(1):21-29.

12. Haughney J, Price D, Kaplan A, Chrystyn H, Horne R, May N, et al. Achieving asthma control in practice: understanding the reasons for poor control. Respir Med 2008;102(12):1681-1693. 
13. Appel D. Faulty use of canister nebulizers for asthma. J Fam Pract 1982;14(6):1135-1138.

14. Basheti IA, Armour CL, Bosnic-Anticevich SZ, Reddel HK. Evaluation of a novel educational strategy, including inhaler-based reminder labels, to improve asthma inhaler technique. Patient Educ Couns 2008;72(1):26-33.

15. Giraud V, Allaert FA, Roche N. Inhaler technique and asthma: feasibility and acceptability of training by pharmacists. Respir Med 2011;105(12):1815-1822.

16. Brocklebank D, Ram F, Wright J, Barry P, Cates C, Davies L, et al. Comparison of the effectiveness of inhaler devices in asthma and chronic obstructive airways disease: a systematic review of the literature. Health Technol Assess 2001;5(26):1-149.

17. Al-Doghim I. Evaluation of inhalation technique of metered dose inhaler (MDI) and dry powder inhaler-Turbuhaler (DPI) among pediatric patients with asthma. J J Appl Sci 2007;9(1):53-66.

18. van der Palen J, Klein JJ, Schildkamp AM. Comparison of a new multidose powder inhaler (Diskus/Accuhaler) and the Turbuhaler regarding preference and ease of use. J Asthma 1998;35(2):147-152.

19. Basheti IA, Reddel HK, Armour CL, Bosnic-Anticevich SZ. Counseling about Turbuhaler technique: needs assessment and effective strategies for community pharmacists. Respir Care 2005;50(5):617623.

20. Cain WT, Cable G, Oppenheimer JJ. The ability of the community pharmacist to learn the proper actuation techniques of inhaler devices. J Allergy Clin Immunol 2001;108(6):918-920.

21. Chopra N, Oprescu N, Fask A, Oppenheimer J. Does introduction of new "easy to use" inhalational devices improve medical personnel's knowledge of their proper use? Ann Allergy Asthma Immunol 2002; 88(4):395-400.

22. García-Cárdenas V, Sabater-Hernández D, García-Corpas JP, Faus MJ, Martínez-Martínez F, Benrimoj SI. Errors in Turbuhaler technique in a Spanish population of asthmatic patients (letter). Respir Care 2012;57(5):817-818; author reply 818-819.

23. Epstein S, Maidenberg A, Hallett D, Khan K, Chapman KR. Patient handling of a dry-powder inhaler in clinical practice. Chest 2001; 120(5):1480-1484.

24. Hanania NA, Wittman R, Kesten S, Chapman KR. Medical Personnel's knowledge of and ability to use inhaling devices; metered-dose inhalers, spacing chambers, and breath-actuated dry powder inhalers. Chest 1994;105(1):111-116.

25. Kesten S, Zive K, Chapman KR. Pharmacist knowledge and ability to use inhaled medication delivery systems. Chest 1993;104(6):17371742.

26. Kamps AW, Brand PL, Roorda RJ. Determinants of correct inhalation technique in children attending a hospital-based asthma clinic. Acta Paediatr 2002;91(2):159-163.

27. Khassawneh BY, Al-Ali MK, Alzoubi KH, Batarseh MZ, Al-Safi SA, Sharara AM, Alnasr HM. Handling of inhaler devices in actual pulmonary practice: metered-dose inhaler versus dry powder inhalers. Respir Care 2008;53(3):324-328.

28. Molimard M, Raherison C, Lignot S, Depont F, Abouelfath A, Moore $\mathrm{N}$. Assessment of handling of inhaler devices in real life: an observational study in 3811 patients in primary care. J Aerosol Med 2003;16(3):249-254.

29. Lenney J, Innes JA, Crompton GK. Inappropriate inhaler use: assessment of use and patient preference of seven inhalation devices. Respir Med 2000;94(5):496-500.

30. Smith IJ, Parry-Billings M. The inhalers of the future? A review of dry powder devices on the market today. Pulm Pharmacol Ther 2003;16(2):79-95

31. Lareau SC, Hodder R. Teaching inhaler use in chronic obstructive pulmonary disease patients. J Am Acad Nurse Pract 2012;24(2):113120 .
32. Newman SP. Inhaler treatment options in COPD. Eur Respir Rev 2005;14(96):102-108.

33. Melani AS, Bonavia M, Cilenti V, Cinti C, Lodi M, Martucci P, et al. Inhaler mishandling remains common in real life and is associated with reduced disease control. Respir Med 2011;105(6):930-938.

34. Melani AS, Zanchetta D, Barbato N, Sestini P, Cinti C, Canessa PA, et al. Inhalation technique and variables associated with misuse of conventional metered-dose inhalers and newer dry powder inhalers in experienced adults. Ann Allergy Asthma Immunol 2004;93(5): 439-446.

35. Moore AC, Stone S. Meeting the needs of patients with COPD: patients' preference for the Diskus inhaler compared with the Handihaler. Int J Clin Pract 2004;58(5):444-450.

36. Nelson P, Young HN, Knobloch MJ, Griesbach SA. Telephonic monitoring and optimization of inhaler technique. Telemed J E Health 2011;17(9):734-740.

37. Nimmo CJ, Chen DN, Martinusen SM, Ustad TL, Ostrow DN. Assessment of patient acceptance and inhalation technique of a pressurized aerosol inhaler and two breath-actuated devices. Ann Pharmacother 1993;27(7-8):922-927.

38. Rönmark E, Jögi R, Lindqvist A, Haugen T, Meren M, Loit HM, et al. Correct use of three powder inhalers: comparison between Diskus, Turbuhaler, and Easyhaler. J Asthma 2005;42(3):173-178.

39. Rootmensen GN, van Keimpema AR, Jansen HM, de Haan RJ. Predictors of incorrect inhalation technique in patients with asthma or COPD: a study using a validated videotaped scoring method. J Aerosol Med Pulm Drug Deliv 2010;23(5):323-328.

40. van Beerendonk I, Mesters I, Mudde AN, Tan TD. Assessment of the inhalation technique in outpatients with asthma or chronic obstructive pulmonary disease using a metered-dose inhaler or dry powder device. J Asthma 1998;35(3):273-279.

41. Serra-Batlles J, Plaza V, Badiola C, Morejón E, Inhalation Devices Study Group. Patient perception and acceptability of multidose dry powder inhalers: a randomized crossover comparison of Diskus/Accuhaler with Turbuhaler. J Aerosol Med 2002;15(1):59-64.

42. Sestini P, Cappiello V, Aliani M, Martucci P, Sena A, Vaghi A, et al Prescription bias and factors associated with improper use of inhalers. J Aerosol Med 2006;19(2):127-136.

43. Sleath B, Ayala GX, Gillette C, Williams D, Davis S, Tudor G, et al Provider demonstration and assessment of child device technique during pediatric asthma visits. Pediatrics 2011;127(4):642-648.

44. Steier J, Trammer T, Cloes RM, Petro W. Optical feedback training of inhalation with Autohaler and Turbuhaler in COPD patients. Lung 2003;181(4):183-192.

45. Martin MA, Mosnaim GS, Rojas D, Hernandez O, Sadowski LS. Evaluation of an asthma medication training program for immigrant Mexican community health workers. Prog Community Health Partnersh 2011;5(1):95-103.

46. Basheti IA, Qunaibi E, Bosnic-Anticevich SZ, Armour CL, Khater S, Omar M, Reddel HK. User error with Diskus and Turbuhaler by asthma patients and pharmacists in Jordan and Australia. Respir Care 2011;56(12):1916-1923.

47. Basheti IA, Reddel HK, Armour CL, Bosnic-Anticevich SZ. Improved asthma outcomes with a simple inhaler technique intervention by community pharmacists. J Allergy Clin Immunol 2007;119(6): 1537-1538

48. Haughney J, Price D, Barnes NC, Virchow JC, Roche N, Chrystyn H. Choosing inhaler devices for people with asthma: current knowledge and outstanding research needs. Respir Med 2010;104(9):12371245 .

49. Fink JB. Inhalers in asthma management: is demonstration the key to compliance? Respir Care 2005;50(5):598-600.

50. Ekström T, Andersson AC, Skedinger M, Lindbladh C, Ståhl E. Dose potency relationship of terbutaline inhaled via Turbuhaler or 


\section{Checklists for Powder Inhaler Technique}

via a pressurized metered dose inhaler. Ann Allergy Asthma Immunol 1995;74(4):328-332.

51. Meakin BJ, Cainey JM, Woodcock PM. Simulated 'in-use' and 'misuse' aspects of the delivery of terbutaline sulphate from Bricanyl Turbuhaler dry powder inhalers. Int J Pharm 1995;119(1):103-108.

52. Hansen OR, Pedersen S. Optimal inhalation technique with terbutaline Turbuhaler. Eur Respir J 1989;2(7):637-639.

53. Meakin BJ, Cainey JM, Woodcock PM. Drug delivery characteristics of Bricanyl Turbohaler dry powder inhalers. Int J Pharm 1995; 119(1):91-102.

54. Engel T, Scharling B, Heinig JH. Effects, side effects and plasma concentrations of terbutaline in adult asthmatics after inhaling from a dry powder inhaler device at different inhalation flows and volumes. Br J Clin Pharmacol 1992;33(4):439-444.

55. Broeders ME, Molema J, Hop WC, Vermue NA, Folgering HT. The course of inhalation profiles during an exacerbation of obstructive lung disease. Respir Med 2004;98(12):1173-1179.

56. Lavorini F, Magnan A, Dubus JC, Voshaar T, Corbetta L, Broeders $\mathrm{M}$, et al. Effect of incorrect use of dry powder inhalers on management of patients with asthma and COPD. Respir Med 2008;102(4): 593-604.

57. Laube BL, Janssens HM, de Jongh FH, Devadason SG, Dhand R, Diot $\mathrm{P}$, et al. What the pulmonary specialist should know about the new inhalation therapies. Eur Respir J 2011;37(6):1308-1331.

58. Borgström L, Asking L, Thorsson L. Idealhalers or realhalers? A comparison of Diskus and Turbuhaler. Int J Clin Pract 2005;59(12): 1488-1495.

59. Newman SP. A comparison of lung deposition patterns between different asthma inhalers. J Aerosol Med 1995;8(Suppl 3):S21-S26; discussion S27.

60. de Boer AH, Bolhuis GK, Gjaltema D, Hagedoorn P. Inhalation characteristics and their effects on in vitro drug delivery from dry powder inhalers: part 3: the effect of flow increase rate (FIR) on the in vitro drug release from the Pulmicort 200 Turbuhaler. Int J Pharm 1997;153(1):67-77.

61. Persson G, Olsson B, Soliman S. The impact of inspiratory effort on inspiratory flow through Turbuhaler in asthmatic patients. Eur Respir J 1997;10(3):681-684.

62. Devadason SG, Everard ML, MacEarlan C, Roller C, Summers QA, Swift $\mathrm{P}$, et al. Lung deposition from the Turbuhaler in children with cystic fibrosis. Eur Respir J 1997;10(9):2023-2028.

63. Abdelrahim ME, Assi KH, Chrystyn H. Dose emission and aerodynamic characterization of the terbutaline sulphate dose emitted from a Turbuhaler at low inhalation flow. Pharm Dev Technol 2013;18(4): 944-949.

64. Azouz W, Chrystyn H. Clarifying the dilemmas about inhalation techniques for dry powder inhalers: integrating science with clinical practice. Prim Care Respir J 2012;21(2):208-213

65. Borgström L. On the use of dry powder inhalers in situations perceived as constrained. J Aerosol Med 2001;14(3):281-287.

66. Nsour WM, Alldred A, Corrado J, Chrystyn H. Measurement of peak inhalation rates with an in-check meter to identify an elderly patient's ability to use a Turbuhaler. Respir Med 2001;95(12):965-968.

67. Chrystyn H. Effects of device design on patient compliance: comparing the same drug in different devices. In: Dalby RN, Byron PR, Peart J, Suman JD, editors. Respiratory drug delivery Europe. Moore, Oklahoma: Davis Healthcare International Publishing; 2009:105-116.

68. Capstick TG, Clifton IJ. Inhaler technique and training in people with chronic obstructive pulmonary disease and asthma. Expert Rev Respir Med 2012;6(1):91-101.

69. Newman SP, Pavia D, Garland N, Clarke SW. Effects of various inhalation modes on the deposition of radioactive pressurized aerosols. Eur J Respir Dis Suppl 1982;119:57-65.

70. Goodman DE, Israel E, Rosenberg M, Johnston R, Weiss ST, Drazen JM. The influence of age, diagnosis, and gender on proper use of metered-dose inhalers. Am J Respir Crit Care Med 1994;150(5 Pt 1):1256-1261.

71. Borgström L, Asking L, Lipniunas P. An in vivo and in vitro comparison of two powder inhalers following storage at hot/humid conditions. J Aerosol Med 2005;18(3):304-310.

72. Giraud V, Roche N. Misuse of corticosteroid metered-dose inhaler is associated with decreased asthma stability. Eur Respir J 2002;19(2): 246-251.

73. Goren A, Noviski N, Avital A, Maayan C, Stahl E, Godfrey S, Springer C. Assessment of the ability of young children to use a powder inhaler device (Turbuhaler). Pediatr Pulmonol 1994;18(2): $77-80$

74. van der Palen J, Klein JJ, van Herwaarden CL, Zielhuis GA, Seydel ER. Multiple inhalers confuse asthma patients. Eur Respir J 1999; 14(5):1034-1037.

75. Price D, Chrystyn H, Kaplan A, Haughney J, Román-Rodríguez M, Burden A, et al. Effectiveness of same versus mixed asthma inhaler devices: a retrospective observational study in primary care. Allergy Asthma Immunol Res 2012;4(4):184-191.

76. Williams AE, Chrystyn H. Survey of pharmacists' attitudes towards interchangeable use of dry powder inhalers. Pharm World Sci 2007; 29(3):221-227 